\title{
LANGUAGES OF THE PEOPLES OF THE RUSSIAN FEDERATION: LEGAL ASPECT OF LANGUAGE POLICY IN A MULTINATIONAL COUNTRY
}

\author{
Vida Yu. Mikhalchenko ${ }^{1}$, Elena A. Kondrashkina ${ }^{2}$, Svetlana V. Kirilenko ${ }^{3 *}$ \\ ${ }^{1}$ Prof. Dr., Head Scientific Researcher, Institute of Linguistics, Russian Academy of Sciences, \\ RUSSIA, vida-mi@mail.ru \\ ${ }^{2}$ Senior Scientific Researcher, Candidate of Sciences (Philology), Institute of Linguistics, Russian \\ Academy of Sciences, RUSSIA, e.kondrashkina@inbox.ru \\ ${ }^{3}$ Scientific Researcher, Candidate of Sciences (Philology), Institute of Linguistics, Russian \\ Academy of Sciences; Assoc. Prof., RUSSIA, svetlanavk@inbox.ru \\ ${ }^{*}$ Corresponding Author
}

\begin{abstract}
The article gives an overview of the history of language legislation development in the Russian Federation, i.e. it considers the formation and implementation of regulations for the use of a language in different spheres of communication, which in the long run contributed to maintaining language well-being, safeguarded peaceful co-existence of languages, helped to avoid providing basis for language conflicts. Language legislation, as a rule, is represented in separate articles of the Constitution, state programs and laws on languages, being a means of the conscious influence of society on languages. Generally speaking, language legislation is to be designed to correspond to the characteristics of a language situation in which it will be applied. Besides, it is to cater to the social needs of a whole society (language unity) and individual language communities (language diversity) to the maximum extent.
\end{abstract}

The adoption of laws that take into account all ethno-cultural factors mentioned above is only one stage on the way towards harmonizing national-language relations. First and foremost, it is crucial to organize proper application and enforcement of those laws. On the one hand, the most important issue is the choice of the correct approach to the language problems in multinational countries, since it is vulnerable grounds where the problems of language unity of a state can arise. On the other hand, language needs of individual linguistic communities are to be taken into account.

By regulating the scope and functional load of the languages-components of the corresponding sociocommunicative system, language legislation creates conditions for language integration in society, protects language rights of individuals. On the contrary, ill-considered language legislation can lead to social tensions and language disintegration.

This article analyzes the laws on languages in the republics of the Russian Federation. A closer attention is paid to the laws on languages in the five Finno-Ugric republics of the Russian Federation, namely Karelia, Komi, Mari El, Mordovia and Udmurtia. In two of them (Mari El and Mordovia), not two languages, as in most other republics, but three ones are declared official languages.

The reasons for so-called 'language nihilism' in Mari El, Mordovia and Udmurtia are considered in article. The explanation of the reason for the rejection of the law on languages in the Republic of Karelia will be given in detail. Furthermore, the authors examine the language assimilation of the Karelian people, which sparked off the decrease in the number of speakers and examine the causes of it.

At the same time, the authors consider critics towards a number of articles of the laws on languages which made these laws optional for implementation. Moreover, as it is reflected in the article, the role of national languages, declared as state languages, is underestimated in some important areas of communication

The paper concludes with a brief overview of the many years of existence of language laws and their 
implementation into practice.

Keywords: laws on languages, language policy, articles on laws on languages, language conflicts, ethnic minorities, demographic factors, Russian language, state language

\section{INTRODUCTION}

After the collapse of the USSR in December 1991, Russia faced the necessity of a fundamental renewal of the federal structure. On the eve of the 1991 presidential elections, Boris N. Yeltsin called on regional leaders to take as much independence as possible and proposed to sign a federal agreement with the center. This statement sparked a surge in national movements and spawned separatist sentiments. Tatarstan, Bashkiria, Yakutsk, Tuva, Buryatia and Chechnya raised the issue of secession from the Russian Soviet Federative Socialist Republic. Those events forced the central government to speed up the conclusion of a federal agreement, which was signed on March 31, 1992 by the representatives of all republics, territories and regions, except for Tatarstan and Chechnya (they signed it later). The essence of the treaty was that the national regions of the country were given broader powers. Russia was becoming a federation. In 1993, the Constitution of the Russian Federation was adopted, which consolidated the basic principles of the federal structure of the country.

\section{OVERVIEW OF THE LANGUAGE LEGISLATION DEVELOPMENT}

Following the restructuring of statehood on a new federal basis, the question of language reform became highly acute. By the end of the 1980s the situation with national languages was simply disastrous. In practice, they were ousted by the Russian language from almost all spheres of public life. The language situation among most peoples, according to the famous Mari scientist Ksenofont N. Sanukov, "has been brought to a point beyond which, it seems, irreversible processes can already occur" [Sanukov, p. 12]. From year to year, the numbers of people who did not know their native languages, who did not want to either speak or study them, did not recognize them as mother tongues, increased. National languages were studied only in primary schools (with the exception for the Tatars, Bashkirs, Yakuts and Tuvinians - they maintained the secondary and higher levels of school education in their native language) and only $9 \%$ of non-Russian children studied in national schools, the rest - all the other pupils studied in Russian language schools. All this caused anxiety and concern of the patriotic part of the non-Russian population in the field. The language situation called for drastic measures. First and foremost, legislative procedures were to be the primary steps.

The first law that was adopted was the Law of the Russian Soviet Federative Socialist Republic 'On the languages of the peoples of the Russian Soviet Federative Socialist Republic' (1991), which proclaimed 'language sovereignty', i.e. 'the totality of the rights of peoples and individuals to preserve and comprehensively develop their native language, freedom of choice and use of the language of communication'. At the same time the law guaranteed, 'the language sovereignty of each people, regardless of the size and legal status, and the language sovereignty of an individual, regardless of the origin of the person, their social and property status, race and nationality, gender, education, attitude to religion and place of residence'(Chapter 1, Article 2). The Law stated that 'the Russian language, which is the main means of interethnic communication between the peoples of the Russian Soviet Federative Socialist Republic in accordance with the established historical and cultural traditions, has the status of the state language throughout the territory of the Russian Soviet Federative Socialist Republic'. The republics that were component republics of the Russian Soviet Federative Socialist Republic were given the right to independently make a decision 'on the legal status of the languages of the peoples living in their territories' (Chapter 1, Article 3).

The adoption of the federal law on languages in the republics, led to the start of the process of developing legislative acts. In order to formulate the articles of the law correctly, it was necessary to take into account a number of factors, i.e., the ethnic composition of the population, the methods of settlement, native language loyalty, value orientations and other social factors. The level of the language development was also important for a language that was to receive the status of a state language [Mikhalchenko 2014, pp 25-26]. With little or no experience in drafting and adopting legal documents relating to national languages, the republics often copied the laws on languages, i.e., those laws that were adopted in the union republics of the former USSR. Meanwhile, the position and political status of the republics of the Russian Federation differed in many respects from the status of the union republics. Languages such as Georgian, Armenian, Latvian, 
Estonian, Tajik and others had a fairly strong position in the social life of the local population and functioned in many social and communicative spheres. The languages of the national republics of the Russian Federation were practically not used in many areas, except for primary education, everyday life, family life, national culture and rituals. This was a consequence of the fact that some of them were young-written languages, i.e. the ones that received writing in the XIX - early XX century. In addition, they had insufficient structural development, undeveloped terminological and stylistic systems, poor standardization, and a narrow social base of the literary forms of the languages.

A big obstacle in the spread of national languages was also the demographic factor, namely, in most of the republics Russians constituted the dominant population. They were, as a rule, monolingual and did not speak the language of the titular population of the republics. In addition, even representatives of the titular population did not always speak their native language. Nevertheless, laws on languages were formulated and adopted in the republics. There are 22 republics in the Russian Federation, all of them, except for Karelia, formalized the legal status of their titular languages. The republics of Buryatia, Komi, Sakha (Yakutia), Tatarstan and Khakassia were the first to adopt laws on languages in 1992. In 1993 - the Altai Republic, in 1994 - the Republics of Adygea, Dagestan, North Ossetia-Alania, in 1995 - the KabardinoBalkarian Republic, the Republic of Mari El, in 1996 - the Republic of Ingushetia, the Karachay-Cherkess Republic, in 1998 - the Republic of Mordovia, in 1999 - the Republics of Bashkortostan, Kalmykia, in 2001 the Udmurt Republic, in 2003 - the Republics of Tyva and the Chuvash Republic, in 2007 - the Chechen Republic, in 2017 - the Republic of Crimea (in the first reading) [Oreshkina 2016, pp 842-844].

In most republics there are two official state languages, Russian (as the state language of the Russian Federation) and a national language. But there are a number of exceptions: so there are three state languages in the Republics of Mari El (Russian, Mari Mountainous and Mari Meadow), Mordovia (Russian, Mordovian Mokshan and Mordovian Erzyan), in Crimea (Russian, Ukrainian and Crimean Tatar) and in Kabardino Balkaria (Russian, Kabardian and Balkarian). There are 5 official languages in the KarachayCherkess Republic (Russian, Abaza, Karachai, Nogai, Circassian). In the Republic of Dagestan official languages are Russian language and 13 languages of the peoples of Dagestan. Obviously, a special language policy is needed, so that everyone's right to speak their native languages was safeguarded.

\section{CASE STUDIES}

Let us consider in a better detail the situation in the Finno-Ugric republics of the Russian Federation: Komi, Mari El, Mordovia and the Udmurt Republic. According to the results of the 2010 census, in all these republics the titular nations are in the minority, and the majority of the population are represented by Russians: in Mordovia, Russians make up $53.2 \%$ of the total population, Mordovians - $39.9 \%$; in Komi Russians $61.7 \%$, Komi $22.5 \%$, in the Udmurt Republic - Russians $60 \%$, Udmurts $27 \%$; in Mari El, the Russian population is $45.7 \%$, the Mari $41.8 \%$ [Census, pp $86-88$ ]. This ratio significantly limits the social base and communication space of national languages.

The republics under consideration are characterized by a rural way of settling for the titular nations, which has a consequence of a lower level of education, culture and language competence than those of urban dwellers. As a rule, villagers do not know the literary norms of the language, they use dialects and vernacular. In cities, most often the Russian or Russian-speaking population predominates, and representatives of the titular nations constitute a minority and are subject to strong language assimilation.

The younger generation is characterized by 'language nihilism', which manifests itself in the preference of the Russian language to the native one; youngsters consider than only the Russian language will be useful for them in the future, are reluctant to learn and speak their native languages, which leads to the gradual disappearance of the latter. According to the results of the 2010 census, $18 \%$ of Mordovians, $43.9 \%$ of Udmurts, $20.2 \%$ of Mari and $37.1 \%$ of Komi living in their republics recognized Russian as their native language. This means that the national language in these republics is not becoming a means of communication, but rather an element of cultural heritage or a factor of ethnic identification.

By the beginning of the language reforms in the republics, a drastic situation had developed. Even the speakers of the titular nation did not always speak their native language, not to mention the people from other ethnic groups. However, language laws were enacted in all four republics. The laws confirmed the status of the Russian language and the languages of the titular nations as state ones, declared the rights of citizens to the freedom to choose the language of communication and education. However, the rules of legislative regulation in different republics turned out to be rather heterogeneous. Thus, in the Udmurt Republic, the law provides for the use the state languages on an equal basis of in all these republics or 'other languages by mutual agreement'. However, in chapter $\mathrm{V}$ article 22 the use of the Udmurt language in 
the spheres of industry, agriculture, transport, communications and energy, is allowed with the wording 'if necessary'. We find the same wording in the law of the Republic of Mordovia, but it applies to the use of the Mordovian language (Mokshan or Erzya) in the field of office work, legal proceedings, in state bodies, organizations and enterprises. The clauses 'if necessary' indicate the absence of clear guidelines on the areas where the authorities would declare the mandatory use of state languages.

In the Komi Republic, the law allows the use of the Komi language and Russian language on equal grounds. However, Article 7, Chapter III states that 'office work, meetings, conferences in government bodies of the Republic of Komi, local self-government bodies are to be conducted in Russian. The Komi language can be used along with Russian language'. This wording immediately puts the Komi language in a position of a supplementary language to the Russian language, especially in matters of using the language in local selfgovernment, where it is the national language that often functions.

In the Republic of Mari El, the law on languages does not have such limitations. It appears to be the most thought-out and justified law on languages, since in a number of articles it allows, along with the state languages, the use of 'other languages spoken by the population in places of their compact residence'.

At the same time, in the republics of Mari El and Mordovia, along with Russian, literary variants of the Mari language - Mountain Mari variety and Meadow Mari variety, Mordovian-Moksha variety and Erzya variety were declared the state national languages. The fact that three state languages are officially recognized in Mari El and Mordovia further complicated the implementation of the laws on languages in these republics. The parallel study of two languages in schools for children, and for adults in language courses, became difficult and therefore ineffective. And if we consider that schoolchildren, as a rule, also study Russian and one of the European languages, then with such a load it is almost impossible to get a good command of at least one of the languages. In addition, the law does not stipulate in which cases, for example, the Mountain Mari should be used, when - the Meadow variety, and in what language the mutual communication between the Mountain and Meadow Mari varieties should be carried out. As before, the main criterion for using a language is the place of residence of its speakers, i.e. in the places where the Mountain Mari live, they speak the Mountain Mari, the same is true for the Meadow Mari variety. Among themselves, the Mountain Mari and Meadow Mari people prefer to communicate in Russian, due to the fact that $98.2 \%$ of the Mari people know it well (according to the 2010 census). A similar picture is observed in other Finno-Ugric republics: in Mordovia, representatives of the Mordovian population showed the highest result in Russian language proficiency $99.5 \%$, in the Udmurt Republic - 99\%, in the Komi Republic - 98.8\%, i.e., practically, the entire titular population of the republics knows Russian well.

When implementing laws on languages, it becomes necessary to resolve a number of issues:

1) to help promote the language declared as the state one among the speakers of the titular nation, since it is impossible to force other language communities (for example, Russians living in the republics) to learn a language that is not known by them and is used by speakers of the titular nation;

2) take practical measures to develop the functional styles of a language, i.e. in the areas of business, scientific communication, etc., the creation of terminology, publications of scientific and scientific-methodical literature [Mikhalchenko 1994, p. 149].

The Federal Law on the Languages of the Russian Federation, having confirmed the status of the Russian language as the state language, thus recognized the bilingual model of language existence in the republics; the task now was to transform the one-sided national-Russian bilingualism into a balanced one, i.e. Russiannational bilingualism should also be present, and for this it was necessary to take steps so as to change the social attitudes of Russian and Russian-speaking communities, since they adhered to a monolingual orientation. The task was difficult given the fact that Russians constitute the majority of population. Moreover, the Russian language had the dominant position in all social and communicative spheres.

After the adoption of laws on languages in the republics, programs for their implementation were developed, where many necessary measures were planned for the development of titular languages.

Undoubtedly, giving the national languages the status of state languages was of great positive importance, since it increased the level of ethnic self-awareness of their speakers and made it possible to begin work on expanding their use. But many questions remained unresolved and, as native speakers themselves admit, the state of their native languages leaves much to be desired.

In order for national languages to be official not only in the texts of laws, but also in real life, it is necessary to promote them and expand their areas of use with the help of the activities in republican state bodies and organizations, judicial institutions, in law enforcement agencies, in office work, in transport, in the field of 
social services, in high school and high school, on radio and television.

Unfortunately, after a period of some upsurge and euphoria at the end of the XX century, at the beginning of the XXI century, in the implementation of laws on languages suspended. Thus, according to the Ministry of Culture, Press and Interethnic Relations of the Republic of Mari El, in the 1999-2000 academic year, the percentage of those studying the Mari language in all schools of the total number of students was $58.4 \%$. In 2001, this percentage increased to $60.3 \%$, in 2001-2002 it fell sharply to $52.7 \%$, and in 2003 a systematic reduction of village schools began under the pretext of 'optimization' of educational institutions. By 2004, the number of students studying the Mari language dropped to 52,847 compared to 72,533 people in the ethnic group in 2001 (these figures were given by the chairman of the interregional public organization 'Mariy Ushem' N.F. Maksimova).

The main reason for the low prestige of national languages is their lack of language prestige, the absence of a clear state policy for the preservation of the cultures of national minorities.

Meanwhile, studies of the dynamics in the development of national titular languages lead to the conclusion that all these languages have good capacity for functional growth. Even in those areas where, starting from the period of language construction in the 1920s, they received an impetus for development (school, press, fiction, theatre), these languages are used very limitedly. The adoption of laws on languages is undoubtedly a necessary and useful matter, but the laws must work, otherwise they remain just beautiful phrases on paper.

Let us now dwell in a better detail on the language situation and language policy in the Republic of Karelia, which is the only republic of the Russian Federation where the titular ethnic group is Karelians, and the Karelian language does not have the status of a state language and the law on languages has not been adopted. Nevertheless, it is considered a region that pays a lot of attention to the protection of the cultural and language rights of peoples. From 1991 to the beginning of the XXI century, more than 20 normative legal acts (laws, decrees, government orders, programs, concepts) were adopted in the republic directly protecting the cultural and language interests of the peoples of the republic, first of all - the Karelians, Vepsians and Finns.

According to the 2010 census, there were 643,548 people in Karelia, among them the majority were representatives of the following ethnic groups: Russians 507634 people (78\%), Karelians 45570 people (7.1\%), Belarusians 23345 people (3.6\%), Ukrainians 12677 people (2\%), Finns 8577 people (1.3\%), Vepsians 3423 people (0.5\%). In total, representatives of about 100 nationalities reside in Karelia.

The Karelian language has three dialects - Karelian, Ludikovsky and Livikovsky (or Olonetsky). The differences between them are so great that there is no mutual intelligibility.

In Soviet times, the Karelian language, which had no literary and written traditions, was in a difficult situation, since it had to compete with the Finnish language, which in the post-October period played a domineering role in the language situation of Karelia. In those years, the thesis was put forward about the inconsistency of the Karelian language and it was considered inappropriate to create a written language for it. It was suggested to use Finnish as the written language. In 1921, the First All-Karelian Congress of Soviets was held in whose resolution it was noted that "the Russian language is the native cultural language for the majority of Karelians" and 'the revival of Karelian literacy is an unnecessary and impossible task' [Kruchkova, p. 173]. The Second All-Karelian Congress of Soviets in October 1922 again concluded that it was impossible to create a Karelian literary language and concluded: 'conducting cultural and educational work among the Karelian population is possible only in Russian and Finnish'. In schools, it was recommended to use Russian and Finnish languages, when students and their parents voluntarily chose the language of education. However in 1929, by the decision of the Karelian Regional Committee of the All-Union Communist Party of Bolsheviks, the task was set to promote the Finnish language as mandatory one among the Karelian population of the republic. In schools, teaching was introduced in Finnish, and Russian language was studied as a subject. In the early 1930s, a writing based on the Latin alphabet was created for the Tver Karelians.

The 1930s made their own adjustments to the life of the Karelian people. The compulsory study of the Finnish language was condemned as a manifestation of bourgeois nationalism, and from January 1938 the use of the Finnish language in the education and publishing system was prohibited. In 1937, on the basis of the Cyrillic alphabet, the Karelian writing system was established for the Karelians of the Karelian ASSR. Preparations began for the creation of a Karelian literary language based on Russian graphics. The researcher of the Finno-Ugric languages prof. D.V. Bubrikh developed the norm of the Karelian language, which was in fact a levelized inter-dialect variety. School books and dictionaries were prepared for 
publication, children's books were translated from the Russian language into Karelian; in total, about 200 editions were published.

However, the literary Karelian language was not widely spoken for two reasons. First, the standardized variety turned out to be difficult to understand or was even completely incomprehensible to the speakers of almost all dialects. Therefore, it was necessary to overcome certain psychological barrier of the population in order to introduce it into the sphere of education or into other spheres. Secondly, the introduction of a standardized written Karelian language into practice took place in a very short period, since in 1940 the Karelian ASSR was transformed into the Karelo-Finnish ASSR and teaching in all national schools was again transferred into Finnish. The Karelian language as a written language ceased to function.

In 1956 Karelia was given back its former name - KASSR, and compulsory education in Finnish was cancelled. Students were supposed to choose, either to study in Finnish or Russian. Since the knowledge of Russian offered better prospects for the future than the knowledge of Finnish, most Karelian parents opted for sending their children to Russian schools.

In 1987, the Karelian writing system was recreated on a Latin graphic basis, and two varieties were developed: one for the Karelian (northern) variety, another one for the Livvik variety. And in 1988 primary schools started teaching in the Karelian language in rural areas with a compact settlement of the Karelian population and in the city of Olonets.

The main components of the language situation in Karelia are: Russian, Karelian, Vepsian and Finnish languages, and two writing systems: Cyrillic for the Russian language and Latin for the other three languages. The Karelians' command of the Russian language was quite proficient all these years. According to the 2010 census, $99.9 \%$ of the Karelian population of the republic spoke Russian, i.e. almost all Karelians know Russian and actively speak it. At the same time, $72.7 \%$ of Karelians consider it to be their native language, and only $27.2 \%$ of Karelians recognize the Karelian language as their native language.

The fact that the Russian and Karelian cultures are in many ways similar was also of great importance. Most of both peoples are Orthodox. Both peoples have lived side by side in the same territory for many years; there have never been any serious ethnic conflicts between them. In addition, the northern type of agriculture, hunting, fishing, common among the Karelians, is in many ways similar to the Russian culture of the neighboring regions. All these factors facilitated the language assimilation of the Karelians, which led to the fact that the number of speakers and knowledge of the Karelian language is decreasing every year, since many families speak Russian and the first language of children in such families is Russian, not Karelian.

On September 3, 1996, the draft law 'On languages in the Republic of Karelia' was published. The text of the law, according to T.B. Kryuchkova, was quite thoughtful and balanced. In article 1, Russian and Karelian languages were declared the state languages. Article 4 guaranteed political, economic, social and cultural rights to all citizens of Karelia, regardless of their knowledge of the state languages. Article 5 guaranteed the rights of the Vepsians, the indigenous small people of the republic, and the rights of the Finns, the rehabilitated people, to preserve and develop their cultures and languages, and their right to receive education in their native language. Article 6 emphasized that no one has the right to impose on a citizen the use of one or another language against his will. The article regulating the use of the language in the state authorities and local self-government ended with the wording: 'if it is impossible to use two state languages, the state language of the Russian Federation (Russian) is used'. However, the authors of the law understood that declaring the Karelian language as the state language would be risky and would be controversial, since there was no standardized literary language, besides it existed in three varieties. So, they assumed that there would be a certain transitional period. As a result, the law has not been adopted until today.

In the Constitution of the Republic of Karelia dated February 12, 2001, the articles directly protecting the cultural and language rights and interests of citizens and peoples include: Art. 11 p. 1, ('The state language of the Republic of Karelia is Russian. The Republic of Karelia has the right to establish other state languages on the basis of the direct expression of the will of the population of the Republic of Karelia through a

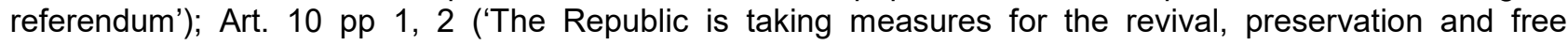
development of indigenous minorities; living on its territory'; 'In the Republic of Karelia, peoples living on its territory are guaranteed the right to preserve their native language, create conditions for its study and development'); Art. 29 p. 2 ('The Republic of Karelia establishes regional (national-regional) components of state educational standards, supports various forms of education, promotes the development of science').

On March 17, 2004, the Legislative Assembly of the Republic of Karelia adopted the Law 'On State Support of the Karelian, Vepsian and Finnish Languages in the Republic of Karelia'. The preamble of the law says: 'The Karelian, Vepsian and Finnish languages are the national heritage of the Republic of Karelia and, along 
with other languages of the peoples of the Republic of Karelia, are under its protection. This Law is aimed at preserving and developing the way of life, culture and languages of the Karelians, Vepsians and Finns, at preserving the historical and national traditions and cultural identity of the Republic of Karelia'. The Law legislates the legal status of these languages (Article 1), guarantees their protection (Article 2), outlines measures for their preservation, study, development and use (Article 3). These measures include: strengthening and expanding the socio-cultural functions of the Karelian, Vepsian and Finnish languages, supporting the media in these languages, organizing an educational system in these languages, publishing educational, scientific and fictional literature, supporting the system of specialists training in the Karelian, Finnish and Vepsian languages and a number of other events have were held. By the order of the Government of the Republic of Karelia dated May 16, 2005, the Republican target program 'State support of the Karelian, Vepsian and Finnish languages in the Republic of Karelia for 2006-2010' was approved, and on June 16, 2005 the Legislative Assembly of the Republic of Karelia adopted this program.

A number of complex measures for the Karelian language were drawn up aiming at the development of the functional load of it for 2009-2020.

Based on the article of the constitution that the Republic of Karelia has the right to declare state languages on the basis of the direct expression of the will of the population through a referendum, since 2015 the country has been discussing the status of the Karelian language as a state language. But the status of a state language obliges to conduct office work and administrative activities in this language, if not on the scale of the republic, then in local authorities. That implies that officials should have good command of a national language, or there will be a need for translators when applying to authorities. In addition, if the Karelian language becomes the state language, its graphics will have to be transferred into Cyrillic, in accordance with the federal law 'On the languages of the peoples of the Russian Federation', although Article 3 of Chapter I of this law states that federal laws for the state languages of the republics may establish other graphic basics. At the same time, the question of a unified Karelian language will arise. According to many public figures, Karelia is objectively not ready for such radical changes. If a referendum takes place, then its results are clear: the demographic majority, which includes not only Russians, but also Belarusians, Ukrainians and other Russian speakers, will vote against.

The complexity of the language situation in Karelia lies in the fact that the functional development and status of languages are different: Russian is the state language and has a long history of normative development as a literary language, and Karelian and Vepsian languages are young-written, mainly languages of oral communication in the closed sphere of family everyday communication, so they cannot compete with Russian language.

\section{CONCLUSION}

Thus, it can be stated that the legal consolidation of the status of state languages for the titular languages of the republics did not solve many of the problems existing in these languages at the present time, and did not provide them with full protection from negative influences.

Conclusions from the above: the existing legislative acts must be improved, on the basis of the data on the current language situation in regions of the Russian Federation.

\section{ACKNOWLEDGEMENT}

The reported study was funded by RFBR and DFG, project number № 21-512-12002 HНИO_a "Prognostic methods and future scenarios in language policy - multilingual Russia as an example"

\section{REFERENCE LIST}

Dictionary of Sociolinguistic Terms (2006). / Mikhalchenko, V.Yu. (ed.) Moscow: Institute of Linguistics, Russian Academy of Sciences.

Kryuchkova, T.B. (2000). The language situation in the Republic of Karelia: history of development and current state // Languages of the Russian Federation and the new abroad. Status and functions. Moscow. pp $168-197$.

Mari. Historical and ethnographic essays (2003). Yoshkar-Ola.

Mikhalchenko, V.Yu. (1994). The concept of laws on languages in the republics of the Russian Federation: 
the problem of social and linguistic adequacy // Language problems of the Russian Federation and laws on languages. Moscow. pp 147-150.

Mikhalchenko, V.Yu. (2014). Variations of national language policy in the modern Russian Federation // Language policy and language conflicts in the modern world. International Conference. Moscow, October 1619, 2014. pp 24-29.

Oreshkina, M.V. (2016). Language legislation in the Russian Federation // Language and society. Encyclopedia. Moscow. pp 835-847.

Oreshkina, M.V. (2020). Language legislation of the Russian Federation: tendencies and problems // Voprosy Philologii, No. 1 (69) 2020. pp 134-138.

Sanukov, K.N. (1994). Finno-Ugric and Finno-Ugric Studies: New Horizons // Finno-Ugric Studies, 1994, No. 1. Yoshkar-Ola. pp 3-15.

Shabaev, Yu.P., Vorontsov, V.S., Orlova, O.V., Martynenko, A.V., Mironova, N.P. (2018). Language policy and language orientations of the population in national republics: a conflict of interests between groups or imperfection of cultural practices (on the example of regions with a Finno-Ugric population)? // Voprosy Philologii. No. 1 (61) 2018. pp 62-74.

Shabykov, V.I. (2016). The value paradigm of public consciousness in the Republic of Mari El (on the material of sociological research). Yoshkar-Ola.

The results of the All-Russian census of 2010 in 11 tons (2012). Volume 4, book 1, Moscow. 